\title{
IMPLEMENTASI DANA DESA DALAM MENINGKATKAN KESEJAHTERAAN MASYARAKAT DESA BERDASARKAN UNDANG-UNDANG NOMOR 6 TAHUN 2014 TENTANG DESA
}

(Study Kasus Desa Poto Tano Kecamatan Poto Tano Kabupaten Sumbawa Barat)

\section{IMPLEMENTATION OF VILLAGE FUNDS IN IMPROVING VILLAGE COMMUNITY WELFARE BASED ON LAW NUMBER 6 OF 2014 CONCERNING VILLAGE (Case Study of Poto Tano Village, Poto Tano District, West Sumbawa Regency)}

\author{
1Ilham Zitri, ${ }^{2}$ Rifaid, ${ }^{3}$ Yudhi Lestanata \\ 1 Universitas Muhammadiyah Mataram \\ 2 Sekolah Tinggi Ilmu Administrasi Mataram \\ 3 Universitas Muhammadiyah Mataram \\ Ilham.zitri@ummat.ac.id
}

\begin{abstract}
ABSTRAK
Dana Desa adalah salah satu kebijakan pemerintah yang diprioritaskan untuk membiayai pembangunan dan pemberdayaan masyarakat yang pelaksanaannya diutamakan secara swakelola dengan menggunakan sumber daya/ bahan baku lokal, dan diupayakan dengan lebih banyak menyerap tenaga kerja masyarakat setempat. Penelitian ini bertujuan untuk mengetahui pemanfaatan dana desa digunakan sesuai dengan program, hasil-hasil dari pemanfaatan dana desa dan keterlibatan masyarakat di Desa Poto Tano Kecamatan Poto Tano Kabupaten Sumbawa Barat. Pendekatan penelitian yang digunakan adalah deskriptif kualitatif. Dengan menggunakan teknik pengumpulan data melalui wawancara kepada informan yang dianggap berpotensi untuk memberikan informasi tentang pemanfaatan Dana Desa dalam pembangunan Desa Poto Tano Kecamatan Poto Tano Kabupaten Sumbawa Barat, juga melalui observasi dan dokumentasi hasil-hasil pemanfaatan Dana Desa. Hasil penelitian menunjukkan bahwa Pemanfaatan Dana Desa Dalam Meningkatkan Kesejahteraan Masyarakat Desa Poto Tano Kecamatan Poto Tano Kabupaten Sumbawa Barat, Berdasarkan Undang-Undang Nomor 6 Tahun 2014 Tentang Desa belum dapat dikatakan efektif. Hal ini dapat dibuktikan dengan jumlah program-program Pemberdayan Masyarakat yang masih berbanding jauh dengan banyaknya program Pembangunan Desa yang telah terealisasi sesuai dengan rencana bentuk program yang telah ditetapkan Pemerintah Desa melalui Musrenbangdes. Keterlibatan masyarakat dalam pelaksanaan pemanfaatan dana desa di Desa Poto Tano juga masih belum dapat dikatakan baik, dimana masyarakat masih belum sepenuhnya diikut sertakan dalam penyusunan sampai pada pelaksanaan program-program yang telah ditetapkan pada saat dilaksanakan musrenbangdes.
\end{abstract}

Kata kunci: Implementasi; Dana Desa; Kesejahteraan Masyarakat. 


\section{ABSTRACT}

The Village Fund is one of the government policies that is prioritized to finance the development and empowerment of the community, the implementation of which is prioritized by using self-managed resources / local raw materials, and strived by absorbing more local workforce. This study aims to determine the use of village funds used in accordance with the program, the results of the use of village funds and community involvement in the Village of Poto Tano, District of Poto Tano, West Sumbawa Regency. The research approach used is descriptive qualitative. Using data collection techniques through interviews with informants who are considered to have the potential to provide information about the use of the Village Fund in the development of Poto Tano Village, Poto Tano Subdistrict, West Sumbawa Regency, also through observation and documentation of the results of the utilization of the Village Fund. The results showed that the Utilization of Village Funds in Improving the Welfare of Poto Tano Village, Poto Tano Subdistrict, West Sumbawa Regency, Based on Law Number 6 of 2014 concerning Villages could not be said to be effective. This can be proven by the number of Community Empowerment programs that are still far different from the number of Village Development programs that have been realized in accordance with the plan of the program set by the Village Government through the Musrenbangdes. Community involvement in the implementation of the use of village funds in Poto Tano Village also cannot be said to be good, where the community is still not fully included in the preparation up to the implementation of the programs that were set at the time of the Musrenbangdes.

Keywords: Implementation; Village Funds; Public welfare.

\section{PENDAHULUAN}

Desa merupakan representasi dari kesatuan masyarakat hukum yang telah ada dan tumbuh berkembang seiring dengan sejarah kehidupan masyarakat Indonesia dan menjadi bagian yang tidak terpisahkan dari tatanan kehidupan bangsa Indonesia. Sebagai wujud pengakuan Negara terhadap Desa, khususnya dalam rangka memperjelas fungsi dan kewenangan desa itu sendiri, ikut serta memperkuat kedudukan desa dan masyarakat desa sebagai subyek pembangunan desa diperlukan kebijakan penataan dan pengaturan mengenai desa yang diwujudkan dengan ditetapkannya Undang-Undang Nomor 6 Tahun 2014 Tentang Desa.

Lahirnya Undang-Undang Nomor 6 Tahun 2014 Tentang Desa telah memperkuat keberadaan desa yang ada sebagai salah satu dari berbagai lembaga di Negara Kesatuan Republik Indonesia. Undang-Undang Nomor 6 Tahun 2014 Tentang Desa juga dapat memperjelas tugas, fungsi dan peran suatu desa dalam 
mengelola, menjalankan dan memberikan pelayanan bagi masyarakat desanya guna tercapainya cita-cita dalam meningkatkan kesejahteraan masyarakat desa. Undangundang ini juga memberikan hak yang seluas-luasnya pada desa atau pemerintah desa untuk mengatur wilayahnya sendiri serta mengatasi masalahnya sendiri sebagai daerah otonom.

Guna mendukung pelaksanaan tugas dan fungsi desa dalam penyelenggaraan pemerintahan dan pembangunan desa dalam segala aspeknya sesuai dengan kewenangan yang dimilikinya, Undang-Undang Nomor 6 Tahun 2014 Tentang Desa memberikan mandat pada Pemerintah Desa untuk mengalokasikan Dana Desa dan sangat diharapkan Pemerintah Desa juga untuk mampu mensejahterakan masyarakatnya sendiri, meningkatkan pembangunan desa, serta melaksanakan otonominya sendiri. "Dana Desa tersebut dianggarkan setiap tahun dalam APBN yang diberikan kepada setiap desa sebagai salah satu sumber pendapatan desa. Kebijakan ini sekaligus mengintegrasikan dan mengoptimalkan seluruh skema pengalokasian anggaran dari pemerintah kepada desa yang selama ini sudah ada".

Salah satu Kebijakan yang mengiringi ditetapkannya Undang-Undang Nomor 6 Tahun 2014 Tentang Desa yaitu Kebijakan Dana Desa. Dana Desa, sebagaimana telah dinyatakan dalam Peraturan Pemerintah Nomor 60 Tahun 2014 Tentang Dana Desa yang bersumber dari Anggaran Pendapatan dan Belanja Negara (APBN), adalah dana yang bersumber dari Anggaran Pendapatan dan Belanja Negara yang diperuntukan bagi desa yang di terima melalui Anggaran Pendapatan dan Belanja Daerah (APBD) dan digunakan untuk membiayai penyelenggaraan pemerintah, pelaksanaan pembangunan, pembinaan kemasyarakatan, dan pemberdayaan masyarakat.

Pada dasarnya Dana Desa bertujuan untuk membangun perekonomian yang inklusif dengan lebih memeratakan pendapatan. Melalui Dana Desa yang jumlahnya cukup besar bahkan nominalnya mencapai milyaran rupiah diharapkan mampu menciptakan berbagai program dan kegiatan pembangunan desa guna mewujudkan kesejahteraan masyarakat. Dalam Undang-Undang Nomor 6 Tahun 2014 Tentang Desa Pasal 1 menyatakan bahwa Dana Desa adalah dana yang bersumber dari Anggaran Pendapatan dan Belanja Negara yang diperuntuhkan bagi Desa yang ditransfer melalui Anggran Pendapatan Belanja Daerah Kabupaten/Kota dan 
digunakan untuk membiayai penyelenggaraan pemerintahan, dan pemberdayaan masyarakat. Dari ulasan diatas maka dapat memperjelas bagaimana seharusnya Pemerintah Desa dalam memanfaatkan dan menggunakan Dana Desa agar tercapainya cita-cita bersama dalam rangka meningkatkan kesejahteraan masyarakat.

Dana Desa dikelola secara tertib, taat pada ketentuan peraturan perundangundangan, efisien, ekonomis, efektif, transparan, dan bertanggungjawab dengan memperhatikan rasa keadilan dan kepatuhan serta mengutamakan kepentingan masyarakat. Penggunaan Dana Desa berdasarkan Pasal 25 Peraturan Menteri Keuangan Nomor 247 Tahun 2015, yaitu: Dana Desa di prioritaskan untuk membiayai pembangunan dan pemberdayaan masyarakat yang pelaksanaannya diutamakan secara swakelola dengan menggunakan sumber daya / bahan baku lokal, dan diupayakan dengan lebih banyak menyerap tenaga kerja dari masyarakat setempat. Sumber pendapatan Desa berdasarkan Undang-Undang Nomor 6 Tahun 2014 terdiri dari:

1. Pendapatan asli Desa terdiri atas hasil usaha, hasil asset, swadaya dan partisipasi, gotong royong, dan lain-lain pendapatan asli Desa;

2. Alokasi anggaran Pendapatan dan Belanja Negara;

3. Bagian dari hasil pajak daerah dan retribusi daerah Kabupaten/Kota;

4. Alokasi dana Desa yang merupakan bagian dari dana perimbangan yang diterima Kabupaten/Kota;

5. Bantuan keuangan dari Anggran Pendapatan dan Belanja Daerah Provinsi dan Anggran Pendapatan dan Belanja Daerah Kabupaten/Kota;

6. Hibah dan sumbangan yang tidak mengikat dari pihak ketiga; dan

7. Lain-lain pendapatan Desa yang sah.

Kententuan pasal tersebut mengamanatkan kepada Pemerintah Kabupaten untuk mengalokasikan dana perimbangan yang diterima Kabupaten kepada desa dengan memperhatikan prinsip keadilan dengan menjamin adanya pemerataan. Dengan adanya Dana Desa tersebut, maka Pemerintah Desa dituntut untuk mengelola Dana Desa dengan efektif, akuntabel. efektif yang dimaksud adalah sejauh mana target (kuantitas, kualitas dan waktu) yang telah dicapai oleh desa dalam pemanfaatan Dana Desa. Sedangkan Akuntabel adalah tingkatan 
Transparansi dari keberhasilan atau kegagalan yang telah dicapai oleh Pemerintah Desa dalam pemanfaatan Dana Desa.

Menindaklanjuti kebijakan tentang pengelolaan Dana Desa yang dimana harus sejalan dengan pemerintah pusat sebagaimana yang telah disebutkan diatas, Pemerintah Kabupaten Sumbawa Barat sebagai salah satu Kabupaten yang berada di Nusa Tenggara Barat (NTB) menetapkan Peraturan Bupati Tentang Tata Cara Pembagian, Penyaluran, Penggunaan Pelaporan, dan Penetapan Rincian Dana Desa Setiap Desa di Kabupaten Sumbawa Barat, yang didalamnya menyebutkan bahwa jumlah Dana yang di alokasikan ke masing-masing desa dengan melihat keadaan desa itu sendiri, jumlah desa yang ada berdasarkan Peraturan Bupati Sumbawa Barat.

Seiring dengan permasalahan itu, pemerintah juga ikut berbenah dalam memerhatikan pembangunan desa. Hal ini memang tidak lepas dengan logika sederhana dalam kajian fakta bahwa desa seringkali tertinggal dalam berbagai aspek pembangunan jika dibandingkan dengan kota. "Hal ini juga yang memicu arus urbanisasi yang turut serta menimbulkan masalah dalam kota. Oleh karena itu, pembangunan desa akan lebih diperhatikan sebaga cara untuk memutus rantai ketimpangan pembangunan di Indonesia”.

Meningkatnya laporan masyarakat terkait dana desa disebabkan antara lain : dugaan tidak transparans, mark-up, fiktif, proyek tidak sesuai kebutuhan, tidak sesuai aturan dalam pengelolaan dana desa oleh oknum kepala desa. Adanya masalah ini potensi mengakibatkan krisis kepercayaan kepada kepala desa. Data yang kami dapatkan dilapangan, banyak terjadi masalah saat ini karena dana desa. Oleh karena itu kita berharap adanya pelibatan masyarakat yang menyeluruh, pelibatan masyarakat sebagai pengawas, serta bimbingan yang maksimal dari pendamping desa.

Implementasi merupakan suatu tahap realisasi tujuan-tujuan program. Dalam hal ini yang perlu diperhatikan adalah persiapan dalam mengimplementasikan suatu tujuan program yang telah disiapkan oleh pemerintah terkait yaitu, memikirkan dan memperhitungkan secara matang berbagai kemungkinan keberhasilan kegagalan termasuk hambatan-hambatan dan peluang-peluang yang ada dan kemampuan organisasi yang diserahi untuk melaksanakan program (Mulyadi, 2015). Permasalahan pada aspek pembinaan pengelolaan Dana Desa antara lain belum adanya regulasi penetapan standar akuntansi pemerintahan desa dan belum adanya regulasi penyelenggaraan dan pembinaan aparatur desa yang lengkap, mutakhir dan sesuai dengan peraturan yang lebih tinggi. 
Dari banyaknya jumlah penduduk yang ada di Desa Poto Tano Pemerintah Desa Poto Tano dituntut harus maksimal dalam mengelola dan memanfaatkan Dana Desa, agar seluruh program yang dilaksanakan dapat dirasakan oleh seluruh penduduk pada umumnya. Pada penelitian ini mengkaji tentang Dana Desa di wilayah Desa Poto Tano yang merupakan salah satu dari desa yang berada di Kecamatan Poto Tano Kabupaten Sumbawa Barat Nusa Tenggara Barat.

Selain itu pengelolaan Dana Desa juga tidak di imbangi dengan tingkat sumber daya yang dimiliki Aparatur Desa, sehingga dalam implementasinya, Sumber Daya Manusia dari Aparatur Desa masih kurang baik dari segi keterampilan, dan keahlian sehingga Pemerintah Desa merasa kesulitan dengan pengelolaan Dana Desa baik dari perencanaan hingga pertanggungjawaban anggaran. Hal tersebut disebabkan karena kurangnya pemahaman Aparatur Desa mengenai tata cara pengelolaan Dana Desa sehinga banyak program yang telah dilaksanakan hanya bersifat fisik dan masih kurang menyentuh terhadap pemberdayaan masyarakat desa. Imbasnya pada awal tahun anggaran 2019 banyak menuai polemik dari kalangan masyarakat, yang dimana masyarakat masih banyak melakukan protes tentang belum adanya sentuhan program pemberdayaan yang telah direncanakan Aparatur Desa. Penelitian ini penting dilakukan untuk memberikan gambaran sejauh mana pelaksanaan dan pemanfaatan Dana Desa dalam rangka meningkatkan kualitas desa baik berupa pembangunan fisik dalam hal ini sarana dan prasarana serta pemberdayaan masyarakat di desa khususnya di Desa Poto Tano Kecamatan Poto Tano Kabupaten Sumbawa Barat.

Berdasarkan permasalahan yang dialami Desa Poto Tano Kecamatan Poto Tano Kabupaten Sumbawa Barat sebagaiman telah diuraikan diatas maka peneliti tertarik untuk melakukan penelitian tentang bagaimana "Implementasi Dana Desa Dalam Meningkatkan Kesejahteraan Masyarakat Desa Berdasarkan Undang-Undang Nomor 6 Tahun 2014 Tentang Desa”.

\section{METODE PENELITIAN}

Kualitatif yaitu metode penelitian yang digunakan adalah penekanan pada observasi wawancara untuk orang, sebagai lawannya adalah gambaran kondisi objektif secara ilmiah, dimana peneliti adalah instrument kunci, teknik pengumpulan data dilakukan secara triangulasi (gabungan), analisis data bersifat 
induktif dan hasil penelitian kualitatif lebih menekankan makna dari pada generalisasi. "Penempatan lokasi penelitian bagi penelitian ilmiah memang berbagai pertimbangan ilmiah maupun pertimbangan pertimbangan praktisnya. Pertimbangan ilmiahnya, apakah lokasinya tersebut terdapat masalah yang banyak dikaji secara ilmiah, bahwa objek tersebut adalah mudah dijangkau, efektif, dan efisien dari segi waktu dan biaya".

Untuk itu penelitian ini berlokasi di Desa Poto Tano dengan alasan penyusun memilih lokasi penelitian tersebut yaitu, Implementasi Dana Desa Dalam Meningkatkan Kesejahteraan Masyarakat Desa Berdasarkan Undang-Undang Nomor 6 Tahun 2014 Tentang Desa. Penelitian ini akan menggambarkan kondisi alamiah sesuai dengan fakta yang terjadi di lapangan yang berkaitan dengan Implementasi Dana Desa Dalam Meningkatkan Kesejahteraan Masyarakat Desa.

Metode penelitian deskriptif kualitatif adalah metode penelitian yang di gunakan untuk meneliti pada kondisi objek yang alamiah, (sebagai lawannya adalah eksperimen) di mana peneliti adalah sebagai instrumen kunci, teknik pengumpulan data dilakukan secara trianggulasi (gabungan), analisis data bersifat induktif, dan hasil penelitian kualitatif lebih menekankan makna dari pada generalisasi. Objek dalam penelitian kualitatif adalah objek yang alamiah, atau natural setting, sehingga metode penelitian ini sering disebut sebagai metode naturalistic. "Mengemukakan bahwa, situasi sosial untuk sampel atau instrumen sangat disarankan suatu situasi sosial didalamnya menjadi semacam muara dari banyak domain lainnya". Dalam penelitian ini teknik pemilihan informan yang dipergunakan peneliti adalah snowball sampling. Snowball sampling adalah teknik pengambilan sampel sumber data yang pada awalnya jumlahnya kecil kemudian membesar ibarat bola salju yang menggelinding yang lama-lama menjadi besar ${ }^{1}$

\section{HASIL DAN DISKUSI}

Desa Poto Tano adalah daerah yang terhampar dengan dihiasi laut dan perbukitan yang indah. Dilintasi jalan provinsi, disambungkan dengan jalan

\footnotetext{
${ }^{1}$ Pusposari, L. F., Umamah, U., \& Dwi, C. (2019). PEMBERDAYAAN MASYARAKAT BERORIENTASI KEMANDIRIAN (STUDI PADA MASYARAKAT PESISIR KECAMATAN CAMPLONG KABUPATEN SAMPANG). J-PIPS (Jurnal Pendidikan Ilmu Pengetahuan Sosial), 2(1), 42-62.
} 
beraspal menghubungkan kabupaten satu dengan kabupaten yang lain, satu kecamatan dengan kecamatan yang lain, dan satu desa dengan desa yang lain. Desa Poto Tano terbagi kedalam 3 (tiga) dusun yakni Dusun Pinamin, Dusun Poto Tano A, dan Dusun Poto Tano B serta terdiri dari 3 (tiga) Rukun Warga (RW) dan 11 (sebelas) Rukun Tetangga (RT). Mata pencaharian masyarakat Desa Poto Tano adalah sebagian besar nelayan, interaksi sosial masyarakatnya sangat harmonis dan rukun, satu sama lain saling menghargai dan menghormati sehingga tercipta lingkungan yang kondusif, aman, tentam, sejahtera dengan menjunjung tinggi nilainilai kegotongroyongan dalam membangun.

Desa Poto Tano mempunyai luas wilayah 2.220 ha dengan jumlah penduduk 1,239 orang. Sedangkan jumlah Kepala Keluarga 344 KK. Adapun batas wilayah Desa Poto Tano sebagai berikut:

Sebelah utara : Selat Alas

Sebelah selatan: Desa Senayan

Sebelah timur: Alas Barat

Sebelah barat: Selat Alas

Dilihat dari topografi dan kuntur tanah, Desa Poto Tano secara umum berupa laut dan perbukitan yang berada pada ketinggian antara $640 \mathrm{~s} / \mathrm{d} 700 \mathrm{~m}$ diatas permukaan laut. Dengan suhu rata-rata 22 s/d 280 celcius. Orbitasi dan jarak tempuh Desa Poto Tano ke ibu kota kecamatan 1,5 km, dengan waktu tempuh 15 menit dan ke ibu kota kabupaten 34 km dengan waktu tempuh 55 menit.

Gambar. 1

\section{Peta Kawasan Pemukiman Desa Poto Tano}

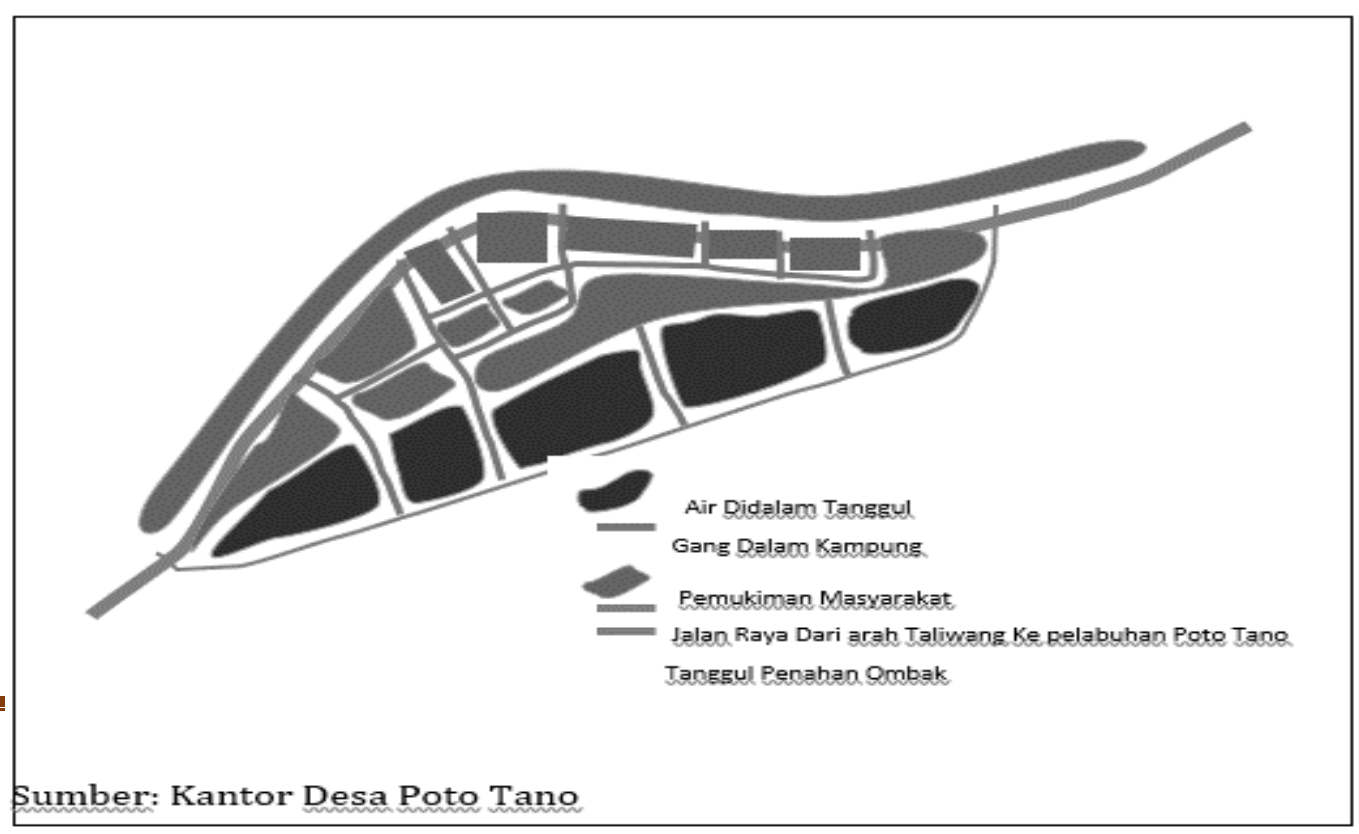


Tabel 1.

Data Jumlah Penduduk Desa Poto Tano

\begin{tabular}{|l|ll|}
\hline Jumlah penduduk & 1.239 & orang \\
\hline Jumlah laki-laki & 601 & orang \\
\hline Jumlah Perempuan & 638 & orang \\
\hline Jumlah Kepala Keluarga & 344 & orang \\
\hline
\end{tabular}

Sumber: Kantor Desa Poto Tano

Pendidikan adalah hal yang sangat penting dalam membentuk sumber daya manusia yang berkualitas sebagai modal utama pembagunan bangsa. Dalam hal ini, tingkat pendidikan yang diterima oleh masyarakat yang memiliki pendidikan formal maupun non formal yang nantinya dapat mempengaruhi kemampuan berpikir dan bertindak lebih dinamis dibandingkan dengan masyarakat tingkat pendidikan yang rendah atau tidak memiliki pendidikan sama sekali. Adapun keadaan pendidikan penduduk Desa Poto Tano Kecamatan Poto Tano Kabupaten Sumbawa Barat menurut tingkat pendidikan dapat dilihat pada Tabel berikut :

Tabel 2

Tingkat Pendidikan Penduduk Desa Poto Tano

\begin{tabular}{|l|l|l|}
\hline Tingkat Pendidikan & Laki-laki & Perempuan \\
\hline $\begin{array}{l}\text { Usia 3-6 Tahun yang belum masuk } \\
\text { sekolah }\end{array}$ & 11 orang & 10 orang \\
\hline $\begin{array}{l}\text { Usia 3-6 Tahun yang sedang TK atau } \\
\text { Play Group }\end{array}$ & 25 orang & 23 orang \\
\hline $\begin{array}{l}\text { Usia 7-18 Tahun yang tidak pernah } \\
\text { sekolah }\end{array}$ & - & - \\
\hline Usia 7-18 Tahun yang sedang sekolah & 89 orang & 62 orang \\
\hline $\begin{array}{l}\text { Usia 18-56 Tahun yang tidak pernah } \\
\text { sekolah }\end{array}$ & - & - \\
\hline $\begin{array}{l}\text { Usia 18-56 Tahun pernah SD tapi tidak } \\
\text { tamat }\end{array}$ & 8 orang & 11 orang \\
\hline Tamat SD Sederajat & 156 orang & 189 orang \\
\hline $\begin{array}{l}\text { Jumlah usia 12-56 tahun tidak tamat } \\
\text { SLTP }\end{array}$ & 26 orang & 23 orang \\
\hline $\begin{array}{l}\text { Jumlah usia 18-56 tahun tidak tamat } \\
\text { SLTA }\end{array}$ & 3 orang & 5 orang \\
\hline Tamat SMP sederajat & 254 orang & 289 orang \\
\hline Tamat SMA sederajat & 15 orang & 18 orang \\
\hline Tamat D1/Sederajat & - & - \\
\hline Tamat D2/Sederajat & - & - \\
\hline Tamat D3/Sederajat & - & - \\
\hline Tamat S1/Sederajat & 9 orang & 2 orang \\
\hline
\end{tabular}




\begin{tabular}{|l|l|l|}
\hline Tamat S2/sederajat & - & - \\
\hline Tamat S3/Sederajat & - & - \\
\hline Tamat tamat SLB A & - & - \\
\hline Tamat tamat SLB B & - & - \\
\hline Tamat tamat SLB C & - & - \\
\hline Jumlah & 596 orang & 632 orang \\
\hline
\end{tabular}

Sumber: Kantor Desa Poto Tano

Tabel 3.

Mata Pecaharian Pokok Penduduk Desa Poto Tano

\begin{tabular}{|c|c|c|}
\hline Jenis Pekerjaan & Laki-laki & Perempuan \\
\hline Petani & - & - \\
\hline Buruh tani & - & - \\
\hline Buruh migran Perempuan & - & - \\
\hline Buruh migran Laki-laki & - & - \\
\hline Pegawai Negeri Sipil & 13 orang & 3 orang \\
\hline Pengrajin Industri Rimah Tangga & - & - \\
\hline Pedagang Keliling & - & - \\
\hline Peternak & 73 orang & - \\
\hline Nelayan & 263 orang & - \\
\hline Montir & - & - \\
\hline Dokter swasta & - & - \\
\hline Bidan swasta & - & - \\
\hline Perawat swasta & - & - \\
\hline TNI & 1 orang & - \\
\hline Polri & - & - \\
\hline Pensiunan PNS/TNI/Polri & - & - \\
\hline Pengusaha kecil dan menengah & - & - \\
\hline Pengacara & - & - \\
\hline Notaris & - & - \\
\hline Dukun Kampung Terlatih & - & 1 oang \\
\hline Jasa Pengobatan Alternatif & - & - \\
\hline Dosen Swasta & - & - \\
\hline Pengusaha Besar & - & - \\
\hline Arsitektur & - & - \\
\hline Karyawan Perusahaan Swasta & 13 orang & - \\
\hline $\begin{array}{l}\text { Karyawan Perusahaan } \\
\text { Pemerintah }\end{array}$ & 27 orang & 6 orang \\
\hline Tukang Batu & 11 orang & - \\
\hline Pedagang & 31 orang & 29 orang \\
\hline Jumlah & 432 orang & 39 orang \\
\hline
\end{tabular}

Sumber: Kantor Desa Poto Tano 
Tabel 4.

Agama Penduduk Desa Poto Tano

\begin{tabular}{|l|l|l|}
\hline \multicolumn{1}{|c|}{ Agama } & \multicolumn{1}{c|}{ Laki-laki } & \multicolumn{1}{c|}{ Perempuan } \\
\hline Islam & 598 orang & 636 orang \\
\hline Kristen & - & - \\
\hline Katholik & - & - \\
\hline Hindu & 3 orang & 2 orang \\
\hline Budha & - & - \\
\hline Khonghucu & - & - \\
\hline Kepercayaan kepada YME & - & - \\
\hline Aliran kepercayaan lainya & - & - \\
\hline Jumlah & 601 orang & 638 orang \\
\hline
\end{tabular}

Sumber: Kantor Desa Poto Tano

Sarana dan prasarana sangat diperlukan untuk menunjang segala aktifitas kehidupan, baik sarana dan prasarana dibidang sosial maupun bidang ekonomi. Semua bentuk fasilitas yang ada di Desa Poto Tano, masih ada beberapa fasilitas yang belum memadai. Seperti yang dipaparkan Sekertaris Desa Poto Tano "Dari segala fasilitas yang ada di Kantor Desa Poto Tano, saya rasa sudah cukup lengkap, kecuali fasilitas yang berupa komputer, dengan keterbatasan komputer yang ada, akan sangat berpengaruh terhadap pelayanan administrasi kami pada masyarakat, karna mengingat jumlah fasilitas tidak memadai dengan banyaknya masyarakat yang dilayani perharinya"

Berdasarkan data di atas maka dapat disimpulkan bahwa mengenai sarana dan prasarana di Desa Poto Tano sudah cukup lengkap kecuali dengan keadaan komputer yang dirasa masih kurang memadai, karena masyarakat yang dilayani setiap harinya tidak kurang dari 25 orang, jadi banyak masyarakat yang mengeluh tentang pelayanan Pemerintah Desa Poto Tano dalam hal administrasi.

Pemanfaatan Dana Desa di Desa Poto Tano dalam program Pemberdayaan Masyarakat dapat dilihat dengan sejauh mana yang dilaksanakan sesuai dengan rencana yang telah disepakati dalam Musrenbangdes dan realisasi atau hasil-hasil dari program yang dilaksanakan tersebut. Dalam penelitian ini untuk mengukur sejauh mana Implementasi Dana Desa yang dilaksanakan Aparatur Desa Poto Tano dalam rangka meningkatkan kesejahteraan masyarakat desanya, peneliti menggunakan Implementasi yang dalam teorinya menyebutkan bahwa ada empat 
variabel yang akan menjadi tolak ukur berhasil atau tidaknya suatu program yang dilaksanakan oleh Aparatur Desa Poto Tano.

Dalam Undang-Undang Nomor 6 Tahun 2014 Tentang Desa, Dana Desa adalah dana yang bersumber dari Anggaran Pendapatan dan Belanja Negara (APBN) yang diperuntukan bagi desa dengan ditransfer melalui Angaran Pendapatan dan Belanja Daerah (APBD) Kabupaten/Kota dan digunakan untuk membiayai penyelenggaraan pemerintahan, pelaksanaan pembangunan, pembinaan kemasyarakatan dan pemberdayaan masyarakat.

Berikut adalah tabel Rencana Anggaran Pendapatan dan Belanja Desa Poto Tano Tahun Anggaran 2019:

Tabel 5.

Rencana Anggaran Pendapatan dan Belanja Desa Poto Tano Tahun Anggaran 2019

\begin{tabular}{|l|l|l|l|}
\hline No & Uraian & Anggaran & Ket \\
\hline 1 & $\begin{array}{l}\text { 1. Pendapatan } \\
\text { Desa/Transfer } \\
\text { 1.1 Dana Desa }\end{array}$ & Rp. 2.298.144.240.68 & - \\
& $\begin{array}{l}\text { 1.2 Bagian Dari Hasil Pajak } \\
\text { dan Retribusi Daerah } \\
\text { Kabupaten }\end{array}$ & Rp. 1.359.701.000.00 & \\
& $\begin{array}{l}\text { Rp. 64.641.240.68 } \\
\text { (ADD) } \\
\text { 1.4 Bantuan Keuangan }\end{array}$ & Rp. 854.802.000.00 & \\
\hline Jumlah Belanja & Rp. 12.000.000.00 & \\
\hline
\end{tabular}

Sumber : APBDes Desa Poto Tano 2019

Berdasarkan uraian di atas maka dapat dilihat bahwa rincian pendapatan Dana Desa di Desa Poto Tano pada Tahun Anggaran 2019 yakni sebanyak Rp. 1.359.701.000.00, Bagian dari hasil Pajak dan Retribusi Daerah Kabupaten yakni sebanyak Rp. 64.641.240.68, Alokasi Dana Desa (ADD) yang didapatkan yakni sebanyak Rp. 854.802.000.00, dan Bantuan Keuangan yang didapatkan yakni sebanyak Rp. 12.000.000.00 sehingga jumlah keuangan Desa Poto Tano pada tahun anggaran 2019 mencapai Rp. 2.298.144.240.68.

Dengan jumlah Dana Desa yang didapatkan Desa Poto Tano pada Tahun Anggaran 2019 yang mencapai sebanyak Rp. 1.359.701.000.00 harusnya sudah mampu menyeimbangkan penggunaan Dana Desa yang diterima dengan dua 
prioritas penggunaan Dana Desa yakni Pembangunan Desa dan Pemberdayaan Masyarakat Desa.

Berdasarkan uraian di atas, maka dapat disimpulkan bahwa Aparatur Desa Poto Tano dalam pengelolaan Dana Desa masih dikatakan kurang baik, merajuk pada fokus penelitian yang ditekankan oleh peneliti yakni Pemberdayaan Masyarakat. Tata cara pengelolaan Dana Desa yang dilaksanakan Aparatur Desa Poto Tano masih lebih fokus pada satu titik saja yakni pada program Pembangunan Desa, dan tidak menyeimbangkan dengan program Pemberdayaan Masyarakat desa, mengingat Sumber Daya Manusia juga merupakan satu hal penting yang perlu dikembangkan, karena akan sangat berpengaruh terhadap meningkatnya perekonomian masyarakat desa dan mengurangi angka kemiskinan yang terjadi di Desa Poto Tano.

Mengenai pengimplementasian Dana Desa yang dilaksanakan oleh Pemerintah Desa Poto Tano, berikut ini peneneliti akan memberikan uraian mengenai pengimplementasian Dana Desa di Desa Poto Tano berdasarkan teori Implementasi:

\section{Komunikasi}

Komunikasi merupakan proses penyampaian informasi dari komunikator kepada komunikan. Sementara itu, komunikasi kebijakan berarti merupakan proses penyampaian informasi kebijakan dari pembuat kebijakan (policy makers) kepada pelaksana kebijakan (policy implementors).

Dalam komunikasi yang terpenting adalah akses informasi, dalam rangka akses informasi. Pemerintah Desa wajib menyebarluaskan rancangan atau rencana yang akan diprogramkan dalam rangka meningkatkan kesejahteraan masyarakat desanya. Penyebarluasan dapat dilakukan melalui media elektronik, atau media cetak yang terbit di daerah yang bersangkutan serta media komunikasi langsung. Jadi suatu program yang dilaksanakan seharusnya diketahui dan dipahami oleh seluruh komponen yang terkait didalamnya.

Mengenai Komunikasi, Pemerintah Desa Poto Tano telah melakukan sesuai dengan peraturan yang ada, seperti yang dipaparkan oleh Kepala Desa Poto Tano, beliau memaparkan: “Apapun bentuk program yang akan dilaksanakan, setiap akan 
dilaksanakan Musrenbangdes kami mengundang setiap tokoh-tokoh atau perwakilan masyarakat Dusun yang ada di Desa Poto Tano".

Pernyataan diatas senada dengan yang dipaparkan oleh ketua Badan Permusyawaratan Desa (BPD) Desa Poto Tano, beliau memaparkan: "Ketika akan dilaksanakan Musrenbangdes disetiap Tahun Anggaran, kami selaku Pemerintah Desa Poto Tano mengundang masing-masing perwakilan atau tokoh masyarakat yang di setiap Dusunnya untuk ikut dalam Musrenbangdes yang dilaksanakan, hal ini akan mendukung tersampaikannya bentuk program yang akan dilaksanakan kepada masyarakat Dusun di Desa Poto Tano".

Hal tersebut dibenarkan oleh Masyarakat Salah Satu Dusun yang ikut serta dalam Musrenbangdes yang dilaksanakan pada Tahun Anggaran 2019, beliau memaparkan: "Setiap dilaksanakan Musrenbangdes, perwakilan dari masingmasing Dusun diundang untuk ikut serta dalam musyawarah yang diselenggarakan Pemerintah Desa, hal tersebut mendukung terwujudnya Pembangunan ataupun Pemberdayaan yang merata untuk setiap Dusun yang ada di Desa Poto Tano".

Berdasarkan ulasan di atas, maka dapat dilihat bahwa Pemerintah Desa Poto Tano dalam menjalankan komunikasi dengan masyarakatnya sudah dapat dikatakan baik, hal tersebut dapat dibuktikan dengan setiap dilaksanakan Musrenbangdes yang diselenggarakan terbuka. Pemerintah Desa Poto Tano mengundang perwakilan masing-masing Dusun yang ada di Desa Poto Tano setiap dilaksanakan musyawarah, hal tersebut disamping memudahkan tersampainya informasi tentang program baik Pembangunan maupun Pemberdayaan juga dapat mewujudkan pembangunan maupun pemberdayaan yang merata di Desa Poto Tano. Untuk mengukur sejauh mana keefektifan komunikasi Implementasi Dana desa di Desa Poto Tano dapat kita lihat pada dimensi berikut :

\subsection{Transmisi (Penyampaian Bentuk Program)}

Dimensi transformasi menghendaki agar informasi tidak hanya disampaikan kepada pelaksana kebijakan tetapi juga kepada kelompok sasaran dan pihak yang terkait. Program yang akan dilaksanakan dalam rangka meningkatkan kesejahteraan masyarakat Desa Poto Tano harusnya telah disosialisasikan baik kepada pihak implementor maupun pihak sasaran atau masyarakat, karena dalam pelaksanaan dan pembuatan program pemberdayaan masyarakat ini melalui proses 
yang panjang dimulai dari perumusan atau penyusunan rancangan program apa yang memang sudah menjadi basic Masyarakat Desa Poto Tano dan dalam hal ini Kepala Desa Poto Tano memberikan tanggung jawab penuh kepada Lembaga Pemberdayaan Masyarakat (LPM) Desa Poto Tano, kemudian program yang telah selesai disusun melalui Musrenbangdes yang dilaksanakan dikantor Desa Poto Tano dan diikuti oleh jajaran Pemerintah Desa Poto Tano serta Kepala Dusun dari berbagai dusun di Desa Poto Tano serta tokoh masyarakat yang memang telah diutus oleh masyarakat dari masing-masing dusun di Desa Poto Tano.

Sosialisasi Program ditingkat pelaksana atau implementor ini telah dilakukan langsung oleh Kepala Desa dan Sekertaris Desa Poto Tano. Sedangkan yang ditunjuk oleh Kepala Desa Poto Tano untuk melakukan sosialisasi pada sasaran atau masyarakat ialah Ketua Lembaga Pemberdayaan Masyarakat Desa Poto Tano dengan jajarannya. Seperti yang telah dipaparkan oleh ketua Lembaga Pemberdayaan Masyarakat (LPM) Desa Poto Tano, beliau memaparkan: "Terkait sosialisasi bentuk program, kami menyampaikan dan mendiskusikan bersama ketika dilaksanakan Musrenbangdes, disamping memudahkan, hal tersebut juga dapat mengurangi penilaian buruk masyarakat tentang keputusan bentuk program yang akan dilaksanakan".

Hal senadapun diungkapkan oleh Wakil Ketua Badan Permusyawaratan Desa (BPD) Poto Tano, beliau menyatakan: "Kami mensosialisasikan bentuk program yang akan dilaksanakan kepada perwakilan masing-masing Dusun yang hadir saat dilaksanakan Musrenbangdes, dan masing-masing perwakilan Dusun akan melakukan sosialisasi pada masyarakat Dusun yang diwakilinya"(Wawancara Pukul 10.32 Wita) Hal tersebut dibenarkan oleh apa yang dinyatakan oleh pemuda perwakilan dari salah satu Dusun, beliau menyatakan: "Kami menerima dan mendiskusikan bentuk program disaat pelaksanaan Musrenbangdes di Desa Poto Tano yang dihadiri oleh seluruh jajaran Pemerintah Desa dan perwakilan masingmasing Dusun di Desa Poto Tano, mengenai penyampaian informasi kepada masyarakat adalah tanggungjawab masing-masing perwakilan setiap Dusun yang hadir dalam pelaksanaan Musrenbangdes".

Berdasarkan ulasan di atas maka dapat disimpulkan bahwa Transmisi atau penyampaian bentuk program Pemberdayaan Masyarakat di Desa Poto Tano sudah 
dapat dikatakan baik, hal tersebut dapat dibuktikan dengan tersampaikan informasi bentuk program Pemberdayaan Masyarakat bukan hanya sampai kepada pihak implementor saja, namun juga sampai pada pihak sasaran atau masyarakat yang akan diikutsertakan dalam pelaksanaan program pemberdayaan masyarakat. Seperti yang dipaparkan langsung oleh Kepala Desa Poto, beliau menyatakan: "Kami selaku Pemerintah Desa Poto Tano berinisiatif untuk menyeimbangkan penggunaan Dana Desa yang diterima setiap tahunnya, namun hal tersebut tidak tercapai karena keadaan infrastruktur yang ada masih sangat memprihatinkan".

Hal tersebut senada dengan yang dipaparkan oleh yang merupakan salah satu perwakilan dari masyarakat Poto Tano, beliau menyatakan: "Dari kedua prioritas penggunaan Dana Desa tersebut sama-sama sangat penting, namun melihat keadaan jalan yang menjadi penghubung dusun lainnya dengan pusat desa masih belum memadai membuat kami harus lebih banyak menggunakan Dana Desa untuk Pembangunan terlebih dahulu".

Berdasarkan ulasan di atas maka dapat disimpulkan bahwa dalam pengimplementasian Dana Desa, Pemerintah Desa Poto Tano belum sepenuhnya dapat dikatakan baik, hal tersebut dapat dibuktikan dengan penggunaan Dana Desa yang cenderung lebih mengutamakan untuk Pembangunan desa, namun hal tersebut tidak sepenuhnya merupakan keputusan dari Pemerintah Desa Poto Tano, melainkan hasil Musrenbangdes yang diikuti oleh seluruh jajaran Pemerintah Desa dan masing-masing perwakilan dari Dusun di Desa Poto Tano.

\subsection{Konsistensi Informasi}

Dimensi konsistensi menghendaki agar informasi yang disampaikan harus konsisten sehingga tidak menimbulkan kebingungan pelaksana kebijakan, kelompok sasaran maupun pihak terkait. Informasi yang terkandung dalam program pemberdayaan masyarakat ini sudah jelas bahwa tujuannya adalah untuk meningkatkan kesejahteraan masyarakat Desa Poto Tano. Pelaksana kebijakan, kelompok sasaran, dan pihak terkait seharusnya sudah mengetahui maksud tujuan program tersebut. Senada dengan pernyataan Salah satu masyarakat desa yang juga merupakan perwakilan dari Dusun, beliau memaparkan: "Ketika dilaksanakan Musrenbangdes, Pemerintah Desa Poto Tano mengundang masing-masing perwakilan setiap Dusun yang ada di Desa Poto Tano, tapi yang jadi masalahnya 
perwakilan yang mengikuti musyawarah tersebut apakah sudah melakukan sosialisasi dimasing-masing Dusun yang diwakilinya atau tidak".

Berdasarkan ulasan yang telah dipaparkan di atas dapat kita lihat bahwa masing-masing perwakilan yang memang telah diutus dari masing-masing Dusun telah mengetahui tentang program Pemberdayaan Masyarakat yang akan dilaksanakan oleh Pemerintah Desa Poto Tano, hal tersebut dapat dibuktikan dengan hadirnya seluruh perwakilan masing-masing Dusun dalam menghadiri Musrenbangdes yang dilaksanakan di Kantor Desa Poto, hanya saja keberlanjutan informasi untuk sampai pada pihak sasaran atau masyarakat belum jelas terlaksana atau tidak.

Berdasarkan temuan yang dipaparkan di atas dapat disimpulkan bahwa konsistensi informasi di Desa Poto Tano masih kurang, hal tersebut disebabkan karena kurangnya rasa tanggungjawab dari masing-masing pihak yang ditunjuk sebagai wakil dari masyarakat setiap Dusun di Desa Poto Tano.

Mengenai pengetahuan masyarakat tentang sosialisasi yang dilaksanakan oleh Aparatur Desa Poto Tano, secara rinci dapat dilihat dari tabel berikut:

Tabel 6.

Pengetahuan masyarakat mengenai sosialisasi program pemberdayaan di Desa Poto Tano

\begin{tabular}{|c|c|c|c|c|}
\hline \multirow[t]{2}{*}{ No } & \multirow[t]{2}{*}{ Pertanyaan } & \multicolumn{2}{|c|}{$\begin{array}{l}\text { Jawaban } \\
\text { Masyarakat (\%) }\end{array}$} & \multirow{2}{*}{$\begin{array}{l}\text { Total } \\
\text { Jumlah } \\
\text { Responden }\end{array}$} \\
\hline & & Y & $\mathrm{T}$ & \\
\hline 1 & $\begin{array}{l}\text { Apakah masyarakat sudah } \\
\text { mengetahui tentang sosialisasi } \\
\text { program Pemberdayaan } \\
\text { Masyarakat? }\end{array}$ & $\begin{array}{l}10 \text { Jiwa } \\
(33.3 \%)\end{array}$ & $\begin{array}{l}20 \text { Jiwa } \\
(66.7 \%)\end{array}$ & $\begin{array}{l}30 \text { Jiwa } \\
(100 \%)\end{array}$ \\
\hline 2 & $\begin{array}{l}\text { Apakah masyarakat mengetahui } \\
\text { apa saja bentuk program } \\
\text { Pemperdayaan masyarakat, dan } \\
\text { kapan akan dilaksanakannya? }\end{array}$ & $\begin{array}{l}7 \text { Jiwa } \\
(23.3 \%)\end{array}$ & $\begin{array}{l}23 \text { Jiwa } \\
(76.7 \%)\end{array}$ & $\begin{array}{l}30 \text { Jiwa } \\
(100 \%)\end{array}$ \\
\hline 3 & $\begin{array}{l}\text { Apakah masyarakat juga terlibat } \\
\text { dalam pelaksanaan program } \\
\text { pemberdayaan }\end{array}$ & $\begin{array}{l}19 \text { Jiwa } \\
(63.3 \%)\end{array}$ & $\begin{array}{l}11 \\
(36.7 \%)\end{array}$ & $\begin{array}{l}30 \text { Jiwa } \\
(100 \%)\end{array}$ \\
\hline
\end{tabular}

Sumber : Data Primer (diolah)

Hasil penelitian yang diperoleh berdasarkan tabel 6 di atas, dalam hal ini peneliti mengajukan beberapa pertanyaan terkait pengetahuan masyarakat dengan adanya program Pemberdayaan Masyarakat yang dilaksanakan Pemerintah Desa 
Poto Tano dengan jumlah responden yakni 30 jiwa, dari 30 jiwa tersebut, pada pertanyaan tentang pengetahuan masyarakat desa mengenai adanya program Pemberdayaan masyarakat yang dilaksanakan Pemerintah Desa Poto Tano hanya 10 dari 30 jiwa saja yang mengetahui bentuk dan waktu pelaksanaan program Pemberdayaan Masyarakat yang akan diselenggarakan oleh Pemerintah Desa Poto Tano, adapun mengenai keikutsertaan masyarakat Desa Poto Tano dalam pelaksanaan program Pemberdayaan Masyarakat desa yakni 19 dari 30 jiwa yang membenarkan bahwa program pemberdayaan tersebut memang benar diikuti masyarakat Desa Poto Tano.

Berdasarkan ulasan di atas maka peneliti dapat menarik kesimpulan bahwa Konsistensi Informasi yang ada di Desa Poto Tano masih sangat kurang, hal tersebut terjadi karna kurangnya rasa tanggungjawab perwakilan masing-masing dusun yang terhadap penyampaian bentuk dan waktu pelaksanaan program yang akan diselenggarakan Pemerintah Desa Poto Tano, hal tersebut berimbas pada berjalan baik atau buruknya program yang akan dilaksanakan, sehingga hanya sebagian dari seluruh masyarakat dusun di Desa Poto Tano yang dapat ikut serta dalam pelaksanaan program pemberdayaan Pemberdayaan Masyarakat Desa Poto Tano.

\section{Sumber Daya}

Sumber daya memiliki peranan penting dalam implementasi kebijakan, bagaimanapun jelas dan konsistensinya ketentuan-ketentuan aturan tersebut, jika para pelaksana kebijakan yang bertanggung jawab untuk melaksanakan kebijakan kurang mempunyai sumber daya untuk melaksanakan kebijakan secara efektif maka implementasi kebijakan tersebut tidak akan efektif. Sebagai daerah otonom Desa Poto Tano tentunya memiliki sumber daya untuk mengimplementasikan kebijakan yang telah dibuat termasuk dalam mengimplementasikan Dana Desa Dalam Meningkatkan Kesejahteraan Masyarakat Desanya sebagai suatu produk asli daerahnya, Sumber daya disini berkaitan dengan segala sumber yang dapat digunakan untuk mendukung keberhasilan implementasi kebijakan. Sumber daya ini mencakup sumber daya manusia dan informasi yang dijelaskan sebagai berikut:

\subsection{Staff}

Implementasi kebijakan tidak akan berhasil tanpa adanya dukungan dari sumber daya manusia yang cukup kualitas dan kuantitasnya. Kualitas sumber daya 
manusia berkaitan dengan keterampilan, profesionalitas, dan kompetensi di bidangnya, sedangkan kuantitas berkaitan dengan jumlah sumber daya manusia apakah sudah cukup untuk melingkupi seluruh kelompok sasaran. Sumber daya manusia sangat berpengaruh terhadap keberhasilan implementasi, jika sumber daya manusianya kurang, maka jelas akan menghambat dalam mengimplementasikan suatu kebijakan.

Sumber daya manusia berkaitan dengan staf atau aparat pelaksana apakah sudah cukup tersedia atau perlu adanya penambahan staf implementor kebijakan. Ketersedian jumlah staf yang cukup menjadi faktor penentu suatu kebijakan. Kegagalan yang sering terjadi dalam implementasi kebijakan salah satunya disebabkan oleh karena staf yang tidak mencukupi, memadai, ataupun tidak kompeten di bidangnya. Namun jumlah staf yang memadai belum menjamin keberhasilan implementasi suatu kebijakan, staf harus mempunyai ketrampilan dan kompetensi dibidangnya masing-masing. Jumlah Pegawai Pada Desa Poto Tano dapat kita lihat pada uraian berikut ini :

Tabel 7.

Jumlah Pegawai Desa Poto Tano

\begin{tabular}{|c|l|c|c|}
\hline \multirow{2}{*}{ No } & \multicolumn{2}{|c|}{ Jabatan } & \multicolumn{2}{c|}{ Jumlah } \\
\cline { 3 - 4 } & & Laki-Laki & Perempuan \\
\hline 1 & Kepala Desa & 1 Jiwa & - \\
\hline 2 & Sekertaris Desa & 1 Jiwa & - \\
\hline 3 & $\begin{array}{l}\text { Badan Permusyawaratan } \\
\text { Desa }\end{array}$ & 9 Jiwa & - \\
\hline 4 & Kasi Pemerintahan & 1 Jiwa & - \\
\hline 5 & Kasi Kesejahteraan & 1 Jiwa & - \\
\hline 6 & Kasi Pelayanan & 1 Jiwa & - \\
\hline 7 & Kaur TU dan Umum & 1 Jiwa & - \\
\hline 8 & Kaur Keuangan & 1 Jiwa & - \\
\hline 9 & Kaur Perencanaan & 1 Jiwa & - \\
\hline 10 & Lembaga Pemberdayaan & 5 Jiwa & 6 Jiwa \\
\hline & Masyarakat (LPM) & & 8 Jiwa \\
\hline & Karang Taruna & 30 Jiwa & 6 Jiwa \\
\hline
\end{tabular}

Sumber : Profil Desa Poto Tano 2019 
Berdasarkan jumlah pegawai pada table 7 di atas, maka dapat dilihat bahwa staff atau pegawai di Desa Poto Tano sudah sangat mencukupi, namun dari banyaknya pegawai diatas masih banyak yang sumber daya manusianya kurang memadai dengan bidang yang telah tetapkan, sebut saja dari pegawai dibidang Lembaga Pemberdayaan Masyarakat (LPM) Desa Poto Tano, masih begitu banyak pegawai yang kualitasnya tidak mencukupi standar yang telah ditetapkan. Seperti yang dipaparkan oleh salah satu masyarakat Dusun Poto Tano yang ikut serta dalam pelaksanaan program Pemberdayaan Masyarakat, beliau memaparkan: "Dari segi kuantitas, pegawai atau staff Desa Poto Tano sudah memadai, namun sangat disayangkan dari segi kualitasnya masih sangat kurang, banyak yang skill dan keterampilannya tidak sesuai dengan bidang penempatannya, hal tersebut mengakibatkan kurang fahamnya dengan kegiatan yang harus dilaksanakannya".

Hal diatas dibenarkan oleh pernyataan Kepala Kaur Keuangan Desa Poto Tano, beliau memaparkan: "Hal tersebut merupakan satu kelemahan kami, karena Tahun 2019 merupakan Tahun Anggaran kedua, saya rasa wajar jika pegawai atau staff di Desa Poto Tano memiliki kualitas yang kurang, karena pada awal Tahun Anggaran, Kepala Desa Poto Tano melakukan banyak perombakan pegawai”.

Berdasarkan apa yang dipaparkan responden di atas, maka dapat disimpulkan bahwa Staff di Desa Poto Tano dari segi kuantitasnya tidak sebanding dengan kualitas yang dimiliki masing-masing staff yang ada, banyak dari staff Desa Poto Tano yang masih bingung dengan apa yang harusnya dilakukan sesuai dengan penempatannya, hal ini akan sangat berpengaruh terhadap efektif atau tidaknya program yang dilaksanakan.

\subsection{Informasi}

Informasi merupakan sumber yang penting dalam implementasi kebijakan. Berdasarkan penelitian yang telah dilakukan peneliti di Desa Poto Tano yaitu Karena pada tahap komunikasi yang kurang jelas otomatis informasi mengenai pelaksanaan kebijakan anggaran Dana Desa ini pun masih kurang. Dalam hal ini Pemerintah Desa Poto Tano masih belum paham dan mengerti mengenai cara pengelolaan Dana Desa, sebut saja pada tahap penyusunan Rencana Anggaran Belanja Desa (RABDes), dan membuat Surat Pertanggung Jawaban Keuangan Desa (SPJK) hanya ada satu dua orang yang bisa, jadi jika staff yang bisa dalam hal 
tersebut sedang ada diluar kota atau sedang ada urusan diluar ranah Desa Poto Tano maka penyusunan Rencana Anggaran Belanja Desa (RABDes) ataupun penyusunan Surat Pertanggung Jawaban Keuangan (SPJK) akan terhambat, hal ini dikarenakan kurangnya Sumber Daya Manusia yang dimiliki Aparatur Desa Poto Tano.

Seperti yang dipaparkan salah satu staff Desa Poto Tano, Beliau memaparkan: "Hal itu merupakan salah satu titik lemah kami, kurangnya komunikasi yang diterima menyebabkan kami tidak bisa dalam penyusunan baik itu Rencana Anggaran Belanja Desa (RABDes) maupun Surat Pertanggungjawaban Keuangan Desa (SPJKDes)" (Wawancara Pukul 10.45 Wita) Hal senada dipaparkan oleh Kepala Dusun, beliau memaparkan: "Hal tersebut memang sering terjadi, semua itu karena kurangnya staff Desa Poto Tano yang memiliki keahlian dalam teknologi informasi, hal tersebut berimbas pada kurangnya kesigapan dalam penyusunan Rencana Anggaran Belanja (RAB) dan Surat Pertanggungjawaban Keuangan (SPJK), dan seharusnya disini kepala Desa lebih sigap dalam menyikapi hal-hal yang dapat menghambat baik penyusunan Laporan maupun pelaksanaan program".

Berdasarkan data yang diperoleh peneliti di atas, maka dapat disimpulkan bahwa mengenai informasi di Desa Poto Tano masih kurang baik, hal tersebut dikarenakan masih minimnya Sumber Daya Manusia yang dimiliki Desa Poto Tano sehingga menyebabkan kurang berjalannya indormasi yang diterima baik untuk pihak implementor ataupun untuk pihak sasaran kebijakan yakni masyarakat Desa Poto Tano.

\section{Disposisi}

Disposisi atau sikap adalah suatu perilaku yang ditunjukkan oleh elemenelemen dari suatu kegiatan implementasi kebijakan untuk mampu menyelaraskan adanya penumbuhan perilaku dari sikap yang ditunjukkan oleh para pengembang kebijakan pemerintah pada subyek dan obyek kebijakan. Termasuk di dalamnya berbagai bentuk program kegiatan dan tindak lanjut dari suatu kegiatan pembangunan. Kecenderungan perilaku atau karakteristik dari pelaksana kebijakan berperan penting untuk mewujudkan implementasi kebijakan yang sesuai dengan tujuan atau sasaran. Karakter penting yang harus dimiliki oleh pelaksana kebijakan misalnya kejujuran dan komitmen yang tinggi. Kejujuran mengarahkan 
implementor untuk tetap berada dalam asa program yang telah digariskan, sedangkan komitmen yang tinggi dari pelaksana kebijakan akan membuat mereka selalu antusias dalam melaksanakan tugas, wewenang, fungsi, dan tanggung jawab sesuai dengan peraturan yang telah ditetapkan. Hal penting yang perlu dicermati pada variabel disposisi yaitu Insentif merupakan salah satu teknik yang disarankan untuk mengatasi masalah kecendrungan para pelaksana adalah memanipulasi data (meminimalisir tindakan pelaksana dalam melaksanakan tindakan berdasarkan kepentingan pribadi).

Implementasi kebijakan tidak akan berjalan sesuai dengan apa yang diharapkan apabila salah satu dari masing-masing bidang yang ada di suatu Lembaga atau Instansi tidak transparansi dalam pemasukan atau pengeluaran dana desa yang ada, maka hal tersebut akan sangat berpengaruh terhadap berjalan atau tidaknya suatu kebijakan yang akan diimplementasikan, sebut saja misalnya seperti pelaksanaan program pemberdayaan yang dilaksanakan oleh Lembaga Pemberdayaan Masyarakat (LPM) Desa Poto Tano, jika dalam pelaksanaan program dana yang dianggarkan masih ditutupi atau tidak diberitahukan terhadap peserta program yang akan dilaksanaka, maka akan timbul suatu kecurigaan tentang penggunaan dana yang dianggarkan untuk melaksanakan Program Pemberdayaan Masyarakat Desa Poto Tano.

Berdasarkan ulasan di atas, ketua Lembaga Pemberdayaa Masyarakat (LPM) Desa Poto Tano, beliau menjelaksakan: "Semua bentuk dana desa yang dianggarkan untuk masing-masing program telah kami paparkan dan jelaskan pada saat dilakukan musyawarah di Desa Poto Tano".

Hal berbeda dengan yang peneliti temukan dilapangan, ada beberapa masyarakat yang peneliti temukan masih belum mengetahui tentang berapa jumlah dana yang dianggarkan dalam pelaksanaan program Pemberdayaan Masyarakat yang diselenggarakan oleh Pemerintah Desa Poto Tano. Seperti pernyataan Masyarakat desa yang merupakan salah satu masyarakat Dusun yang menjadi peserta dalam program Pemberdayaan masyarakat Desa Poto Tano yang dilaksanakan langsung di Kantor Desa Poto Tano, beliau memaparkan: "Mengenai dana yang dianggarkan penyelenggaran program Pemberdayaan Masyarakat 
banyak dari kami yang tidak mengetahui tentang berapa jumlah dana yang dihabiskan dalam program Pemberdayaan Masyarakat".

Senada dengan pernyataan yang dipaparkan masyarakat sebelumnya, salah satu peserta dalam program pemberdayaan masyarakat desa yang dilaksanakan di Desa Poto Tano, beliau memaparkan: "Hal tersebut memang sudah menjadi kebiasaan para penyelenggara program, sebut saja ketika dilaksanakan program Peningkatan Kapasitas Masyarakat dibidang perbengkelan, banyak peserta yang ikut dalam proram Pemberdayaan Masyarakat tidak mengetahui tentang berapa jumlah dana desa yang dihabiskan dalam pelaksanaan program Pemberdayaan Masyarakat".

Berdasarkan ulasan yang telah dipaparkan oleh para responden di atas, mengenai Insentifitas Pemerintah Desa Poto Tano dirasa masih sanagat kurang, lebih jelasnya berikut rincian penilaian yang didapatkan penulis dilapangan mengenai insentif para Aparatur Desa Poto Tano :

\section{Tabel 8}

Penilaian masyarakat terhadap Insentif Aparatur Desa Poto Tano

\begin{tabular}{|c|c|c|c|c|}
\hline \multirow[t]{2}{*}{ No } & \multirow[t]{2}{*}{ Pertanyaan } & \multicolumn{2}{|c|}{$\begin{array}{l}\text { Jawaban } \\
\text { Masyarakat (\%) }\end{array}$} & \multirow{2}{*}{$\begin{array}{l}\text { Total } \\
\text { Jumlah } \\
\text { Responde } \\
\mathrm{n}\end{array}$} \\
\hline & & $\mathrm{Y}$ & $\mathrm{T}$ & \\
\hline 1 & $\begin{array}{l}\text { Apakah Pemerintah Desa } \\
\text { Poto Tano telah } \\
\text { mensosialisasikan jumlah } \\
\text { dana yang dianggarkan } \\
\text { untuk program } \\
\text { Pemberdayaan } \\
\text { Masyarakat Desa Poto } \\
\text { Tano? }\end{array}$ & $\begin{array}{l}16 \text { Jiwa } \\
(53.3 \%)\end{array}$ & $\begin{array}{l}\text { 14 Jiwa } \\
(46.7 \%)\end{array}$ & $\begin{array}{l}30 \text { Jiwa } \\
(100 \%)\end{array}$ \\
\hline 2 & $\begin{array}{l}\text { Apakah Masyarakat Desa } \\
\text { Poto Tano telah } \\
\text { mengetahui tentang } \\
\text { berapa dana yang } \\
\text { dianggarkan untuk } \\
\text { program Pemberdayaan } \\
\text { Masyarakat. }\end{array}$ & $\begin{array}{l}10 \text { Jiwa } \\
(33.3 \%)\end{array}$ & $\begin{array}{l}20 \text { Jiwa } \\
(66.7 \%)\end{array}$ & $\begin{array}{l}30 \text { Jiwa } \\
(100 \%)\end{array}$ \\
\hline 3 & $\begin{array}{l}\text { Apakah penyelenggara } \\
\text { program sudah } \\
\text { melaksanakan program } \\
\text { sesuai dengan atur. }\end{array}$ & $\begin{array}{l}16 \text { Jiwa } \\
(53.3 \%)\end{array}$ & $\begin{array}{l}14 \text { Jiwa } \\
(46.7 \%)\end{array}$ & $\begin{array}{l}30 \text { Jiwa } \\
(100 \%)\end{array}$ \\
\hline
\end{tabular}

\section{Sumber : Data Primer (diolah)}


Berdasarkan hasil yang diperoleh peneliti dilapangan, maka dapat dilihat bahwa masih banyak masyarakat yang tidak mengetahui tentang berapa banyak dana yang dianggarkan untuk program Pemberdayaan Masyarakat Desa Poto Tano.

Berdasarkan data di atas maka dapat disimpulkan bahwa Insentif Pemerintah Desa Poto Tano terhadap masyarakatnya masih sangat kurang, hal tersebut dibutikan dengan masih banyakanya masyarakat yang hanya mengetahui bentuk dan waktu pelaksanaan program Pemberdayaan Masyarakat saja, tetapi banyak masyarakat yang tidak mengetahui tentang jumlah dana yang akan digunakan untuk melaksanakan program Pemberdayaan Masyarakat yang diselenggarakan oleh Pemerintah Desa Poto Tano. dari simpulan tersebut maka sanagat diharapkan kepada Pemerintah Desa Poto Tano untuk meningkatkan tata cara pengimplementasian Dana Desa di pada tahap Insentif agar dapat meminimalisir dugaan-dugaan penyalahgunaan dana yang dianggarkan untuk melaksanakan program Pemberdayaan Masyarakat Desa Poto Tano.

\section{Struktur Birokrasi}

Struktur Birokrasi memiliki pengaruh yang signifikan terhadap implementasi kebijakan. Aspek struktur organisasi ini melingkupi dua hal yaitu mekanisme dan struktur birokrasi itu sendiri. Aspek pertama adalah mekanisme, dalam implementasi kebijakan biasanya sudah dibuat Standart Operation Procedur (SOP). Standar Operating Procedurs (SOP) menjadi pedoman bagi setiap implementator dalam bertindak agar dalam pelaksanaan kebijakan tidak melenceng dari tujuan dan sasaran kebijakan.

Suatu kebijakan publik tidak hanya melibatkan satu orang saja tetapi melibatkan banyak orang termasuk juga banyak pihak. Oleh sebab itu, diperlukan suatu struktur birokrasi yang kuat dan tidak lemah agar kebijakan tersebut dapat diimplementasikan dengan baik dan berhasil. Maka, untuk mengukur lemah atau tidaknya struktur birokrasi dalam implementasi kebijakan anggaran dana desa digunakan beberapa sub indikator yang dikemukakan.

Pada penggunan Dana Desa, Standar Operating Prosedurs (SOPs) telah diatur di dalam Undang-Undang Nomor 6 Tahun 2014 Tentang Desa dan kemudian diatur melalui Peraturan Pemerintah Nomor 8 tahun 2016 sebagai perubahan kedua atas 
Peraturan Pemerintah Nomor 60 tahun 2014 Tentang Dana Desa yang bersumber dari Anggaran Pendapatan dan Belanja Negara (APBN). Dalam penelitan ini pelaksanaan kebijakan anggaran Dana Desa di Desa Poto Tano dinilai masih belum sesuai dengan prosedur yang telah ditetapkan, hal tersebut dapat dibuktikan dengan masih kurangnya ketransparansian dalam pengelolaan Dana Desa, sebut saja dalam pelaksanaan program pemberdayaan masyarakat dalam bidang peningkatan kapasitas masyarakat dalam bidang perbengkelan, sasaran kebijakan atau masyarakat tidak mengetahui tentang berapa dana yang dianggarkan untuk melaksanakan program Pemberdayaan Masyarakat Desa Poto Tano, merajuk dengan apa yang telah disampaikan oleh peserta Program Pemberdayaan Masyarakat Desa Poto Tano, beliau memaparkan: "Hal tersebut memang sudah menjadi kebiasaan para penyelenggara program, sebut saja ketika dilaksanakan program Peningkatan Kapasitas Masyarakat dibidang perbengkelan, banyak peserta yang ikut dalam proram Pemberdayaan Masyarakat tidak mengetahui tentang berapa jumlah dana yang dihabiskan".

Berdasarkan beberapa ulasan di atas maka penulis dapat menyimpulkan bahwa implementasi Dana Desa dalam hal Standar Operating Prosedurs (SOPs) masih kurang, hal tersebut dapat dibuktikan dengan temuan-temuan yang didapatkan peneliti saat melaksanakan penelitian di Desa Poto Tano yakni peneliti menemukan tata pengelolaan Dana Desa yang dilaksanakan Pemerintah Desa Poto Tano tidak sesuai dengan peraturan perundang-undangan yang telah ditetapkan, sebut saja dalam ketranparansian dana yang digunakan dalam pelaksanaan program Pemberdayaan Masyarakat, masih banyak masyarakat yang tidak mengetahui atau masih mempertanyakan tentang jumlah dana yang digunakan Pemerintah Desa Poto Tano dalam pelaksanaan program Pemberdayaan Masyarakat, hal tersebut berimbas pada kekhawatiran masyarakat terhadap penyalahgunaan dana desa yang memang sudah dianggarkan pemerintah pusat untuk kebutuhan Desa Poto Tano untuk program Pemberdayaan Masyarakat Desa Poto Tano. 


\section{KESIMPULAN}

Berdasarkan penelitian yang telah dilakukan, maka peneliti dapat menyimpulkan sebagai berikut : Implementasi Dana Desa Dalam Rangka Meningkatkan Kesejahteraan Masyarakat Desa Poto Tano Berdasarkan UndangUndang Nomor 6 Tahun 2014 Tentang Desa yang dilaksanakan Pemerintah Desa Poto Tano masih belum dapat dikatakan baik dan efektif, hal tersebut dikarenakan Pemerintah Desa Poto Tano belum menyeimbangkan dalam penggunaan Dana Desa, yang dimana dalam penggunaanya masih lebih mengutamakan Pembangunan Desa dan mengenyampingkan Pemberdayaan Masyarakat Desanya, hingga menyebabkan pertumbuhan ekonomi yang berjalan tidak inklusif.

Partisipasi masyarakat dalam pengelolaan Dana Desa yang dilaksanakan Pemerintah Desa Poto Tano masih kurang, hal tersebut dapat dibuktikan dengan hasil penelitian yang dimana masih banyak masyarakat yang mengeluh karena kurangnya pengetahuan tentang bentuk program dan waktu pelaksanaan program yang diselenggarakan Pemerintah Desa Poto Tano. Pemerintah Desa Poto Tano sangat diharapkan menyeimbangkan dalam pengelolaan Dana Desa berdasarkan prioritas penggunaan Dana Desa, mengingat Pemberdayaan Masyarakat juga merupakan satu hal yang penting, dengan meningkatkan sumber daya masyarakat maka akan dapat meningkatkan pertumbuhan perekonomian Masyarakat Desanya. Pemerintah Desa Poto Tano diharapkan lebih banyak mengikutsertakan masyarakatnya dalam pengelolaan Dana Desa, hal tersebut dapat meminimalisir kekhawatiran masyarakat dalam penyalahan penggunaan Dana Desa oleh pihak Pemerintah Desa, disamping itu juga dapat menjadi faktor pendukung berjalannya program yang dilaksanakan.

\section{REFRENSI}

Beratha, I Nyoman. 2004. Desa Masyarakat Desa dan Pembangunan. Jakarta: Ghalia Indonesia. Hal. 4.

Badrudin, Rudy. (2015)Ekonomika Otonomi Daerah, UPP STIM YKPN, Yogyakarta, Widjaja, HAW. 2003. Otonomi Desa. PT. Raja Grafindo Persada. Jakarta: Hlm. 3. Sugiyono. (2016)Memahami Penelitian Kualitatif. Cetakan ke-11, Bandung: Alfabeta. 
Sugiyono. (2016). Metode Penelitian Kuantitatif dan Kualitatif, dan R\&D,Cetakan ke-

26. Bandung: Alfabeta.

Muh. Aris Marfai, \& Widodo. Moralitas lingkungan: refleksi kritis atas krisis lingkungan berkelanjutan. Wahana Hijau (WeHa): Kreasi Wacana.

Lestanata, Y., \& Zitri, I. (2020). Optimalisasi Sektor Pariwisata Pulau Kenawa Guna Meningkatan Pendapatan Asli Desa (PADes). Journal of Governance and Local Politics, 2(1), 25-47.

Undang-Undang Nomor 6 Tahun 2014 Tentang Desa.

Peraturan Pemerintah Nomor 60 Tahun 2014 Tentang Dana Desa.

Peraturan Menteri Keuangan Pasal 25 Nomor 247 Tahun 2015.

Peraturan Pemerintah Nomor 43 Tahun 2014.

Peraturan Menteri Dalam Negeri Nomor 37 Tahun 2007 Tentang Pedoman Pengelolaan Keuangan Desa pada Pasal 18.

Peraturan Desa Poto Tano Tentang Anggaran Pendapatan dan Belanja Desa Tahun Anggaran 2019.

Laporan Rencana Anggaran Pendapatan dan Belanja Desa Poto Tano Tahun Anggaran 2018.

Profil Desa Poto Tano 2018.

Wawancara

Wawancara Kepala Desa

Wawancara BPD

Wawancara Masyarakat Desa 